\title{
Medical History Sequence Number
}

National Cancer Institute

\section{Source}

National Cancer Institute. Medical History Sequence Number. NCI Thesaurus. Code C83336.

An identifier that describes the relative position of medical history data within a series. 